\title{
EFISIENSI REPRODUKSI SAPI PERAH FRIESIAN HOLSTEIN (Studi kasus Di Peternakan Bapak Nur Trianto Desa Ngaglik Kecamatan Srengat Kabupaten Blitar)
}

\author{
Nita Opi Ari Kustanti,SPt, MMA \\ Dosen Program Studi Ilmu Ternak \\ Fakultas Peternakan Universitas Islam Balitar \\ Jl. Majapahit no 04 , Blitar Jawa Timur, Indonesia \\ Email : Nitaopie@gmail.com
}

\begin{abstract}
This research have done at Mr. Nur Trianto's dairy cow breeding, which placed at Ngaglik village, Srengat districk, Blitar, began at $11^{\text {th }}$ until $24^{\text {th }}$ June 2012 . This research in order to know the CR, S/C, and NRR grade of his dairy cows. The materials of this research are 30 dairy cows Friesian Holstein (FH) with $63,3 \%$ as $\mathrm{CR}$ valve, so the conception number is on the standart. Then, $\mathrm{S} / \mathrm{C}$ value is 1,5 , this value shows that $\mathrm{S} / \mathrm{C}$ value in this breeding is very good. And the last is NRR value, it's $63,3 \%$, it means that $63,3 \%$ or 19 dairy cows do not want be inseminated again after the farmer doing artificially insemination. The result of research that Mr. Nur Trianto's breeding has dairy cows with a good fertility and standart in farming management. The suggest for this research is the breeder should always make the note of his cattle's reproduction complete, in order to be able to manage his breeding easier.
\end{abstract}

Key Word: CR, S/C, NRR

\section{Pendahuluan}

Peternakan merupakan salah satu sektor dalam pertanian Indonesia yang cukup menjanjikan. Usaha peternakan sapi di Indonesia terbagi menjadi dua, yaitu peternakan sapi perah dan peternakan sapi potong. Peternakan sapi perah bertujuan untuk mendapatkan produksi susu yang tinggi dengan kualitas yang baik untuk menunjang kecerdasan bangsa. Seiring dengan peningkatan taraf hidup dan pendidikan masyarakat di Indonesia, kesadaran akan pemenuhan gizi yang baik juga meningkat. Hal ini mengakibatkan permintaan akan produk-produk protein hewani seperti susu bertambah. Faktor penting dalam pengelolaan sapi perah adalah sanitasi, pakan, manajemen reproduksi, dan manajemen kesehatan hewan.

Program swasembada daging sapi 2014 (PSDS-2014) merupakan salah satu dari 21 program utama Departemen Pertanian terkait dengan upaya mewujudkan ketahanan pangan hewani asal ternak berbasis sumberdaya domestic. PSDS 2014 merupakan tugas seluruh lapisan masyarakat. Program swasembada daging ini memiliki nilai strategis guna meningkatkan asupan nutrisi pangan terutama yang bersumber dari protein hewani, dan memberikan kontribusi nyata terhadap ketahanan pangan.

Peternakan sapi perah merupakan salah satu bentuk usaha yang sangat potensial untuk dikembangkan di Indonesia dan dapat menghasilkan produk pangan berupa protein hewani, terutama susu dan daging. Kebutuhan susu dan daging di Indonesia sangat besar seiring bertambah pesatnya jumlah penduduk. Jumlah penduduk Indonesia saat ini mencapai sekitar 225 juta orang dengan konsumsi susu 55 gelas (setara dengan 10 liter)/kapita/tahun. Kebutuhan susu nasional saat ini adalah sekitar 6,4 juta liter/hari. Produksi susu nasional saat ini hanya mampu memenuhi sekitar 23,45\% kebutuhan susu nasional, sehingga sisanya $76,55 \%$ masih impor. 
Untuk meningkatkan produksi perlu dilakukan perbaikan bibit. Selain itu faktor reproduksi juga sangat perlu diperhatikan. Faktor-faktor yang dapat mempengaruhi efisiensi reproduksi seperti makanan, tatalaksana (manajemen) dan juga pencegahan penyakit perlu mendapat perhatian yang khusus. Pemberian makanan yang sempurna, perbaikan tatalaksana pemeliharaan ternak, dan tatalaksana pekawinan merupakan salah satu cara efisiensi perkembangbiakan sapi perah. Sistem perkawinan sapi perah adalah dengan menggunakan sistem perkawinan Inseminasi Buatan (IB).

Keberhasilan reproduksi akan sangat mendukung peningkatan populasi dan produksi susu sapi perah. Masih banyak permasalahan yang timbul dalam peternakan seperti, permasalahan pakan dan kesehatan, khususnya gangguan reproduksi. Gangguan reproduksi berdampak pada rendahnya fertilitas induk, sehingga angka kebuntingan dan kelahiran pedet menurun atau dengan kata lain efisiensi reproduksi menurun.

Faktor keberhasilan sapi perah salah satunya tergantung pada penampilan reproduksi. Penampilan reproduksi menyangkut reproduktivitas sapi perah. Penampilan reproduksi yang baik akan menunjukkan nilai efisiensi reproduksi yang tinggi. Produktivitas yang masih rendah tersebut dapat diakibatkan oleh berbagai faktor terutama yang berkaitan dengan manajemen reproduksi. Variabel yang berpengaruh seperti umur pertama kali melahirkan, umur pertama dikawinkan, jumlah perkawinan per kebuntingan dan jarak kelahiran. Ukuran efisiensi reproduksi dalam usaha peternakan sapi perah sangatlah penting, karena untuk mendapatkan produksi susu dan keuntungan yang optimal sangat bergantung kepada pengaturan reproduksi sapi perah tersebut.

Beberapa parameter untuk menilai efisiensi reproduksi antara lain adalah Conception Rate (CR), Service per Conception (S/C), Non Return Rate (NRR). Tujuan dari penelitian ini adalah Penelitian ini bertujuan untuk mengetahui tingkat CR, S/C, dan NRR pada sapi perah friesian holstein di Desa Ngaglik Kecamatan Srengat Kabupaten Blitar.

\section{Materi Dan Metode Penelitian}

Penelitian ini dilaksanakan mulai tanggal 11 sampai dengan 24 Juni 2012, di peternakan sapi perah milik bapak Syaiful Bahri yang berada di Desa Ngaglik Kecamatan Srengat Kabupaten Blitar. Materi yang digunakan dalam penelitian ini adalah sapi perah Friesian Holstein $(\mathrm{FH})$ dengan kriteria masih produktif, dan mempunyai catatan reproduksi yang lengkap. Jumlah kepemilikan sapi perah di peternakan Bapak Syaiful Bahri adalah sebagai berikut:

Tabel 1. Jumlah kepemilikan sapi perah bapak Syaiful Bahri

\begin{tabular}{|c|c|}
\hline JENIS & JUMLAH (Ekor) \\
\hline Pedet & 41 \\
\hline Dara & 11 \\
\hline Induk Laktasi & 129 \\
\hline Induk Kering & 47 \\
\hline Pejantan & 5 \\
\hline Total & 233 \\
\hline
\end{tabular}

Untuk ternak yang dibuat untuk penelitian adalah 30 ekor yang dikawinkan dengan IB menggunakan straw dari Balai Besar Inseminasi Buatan (BBIB) Singosari.

Metode yang digunakan dalam penelitian ini adalah survey, dimana pengambilan data dilakukan dengan cara mengambil langsung catatan reproduksi induk sapi perah FH pada peternakan bapak Syaiful Bahri.Variabel yang di gunakan untuk mengetahui tingkat efisiensi reproduksi keberhasilan kebuntingan melalui inseminasi buatan pada sapi perah FH adalah: 
1. Conception Rate (CR)

Adalah presentase sapi betina yang bunting pada inseminasi pertama, dengan rumus sebagai berikut:

Jumlah betina bunting pada inseminasi pertama

$$
\mathrm{CR}=
$$

2. Service per Conception (S/C)

Adalah angka yang menunjukkan jumlah semen atau straw yang digunakan untuk menghasilkan suatu kebuntingan, dengan rumus sebagai berikut:

Jumlah dosis IB

$$
\mathrm{S} / \mathrm{C}=
$$

\section{Non Return Rate (NRR)}

Adalah presentase hewan yang tidak kembali minta kawin atau bila tidak ada permintaan inseminasi lebih lanjut dalam waktu 28 sampai 35 atau 60 sampai 90 hari, dengan rumus sebagai berikut:

Jumlah sapi yang di IB - jumlah sapi yang kembali di IB

$$
\text { NRR=-10 }
$$

\section{Hasil Pengamatan Dan Pembahasan}

Peternakan sapi perah milik Bapak Syaiful Bahri yang berlokasi di Desa Ngaglik Kecamatan Srengat Kabupaten Blitar ini berdekatan dengan jalan raya sehingga mudah untuk dijangkau transportasi. Lokasi peternakan sapi perah ini berjarak $\pm 50 \mathrm{~m}$ dari jalan raya sehingga segala bentuk kegiatan transportasi dapat berjalan dengan mudah dan lancar. Disamping itu, peternakan ini sudah dijangkau oleh aliran listrik dan telekomunikasi yang merupakan salah satu faktor penting dalam mendirikan sebuah peternakan. Disamping itu peternakan ini berjarak $\pm 30 \mathrm{~m}$ dari pemukiman warga penduduk sehingga polusi yang ditimbulkan akibat dari peternakan ini tidak mengganggu penduduk sekitar. Suhu dilokasi peternakan sekitar $23-26^{\circ} \mathrm{C}$, Nino (2011) mengatakan, sapi perah yang berasal dari daerah iklim sedang berproduksi maksimal pada suhu lingkungan antara $1,1-15,5^{\circ} \mathrm{C}$ tapi masih dapat berproduksi dengan baik pada kisaran $5-21^{\circ} \mathrm{C}$. Apabila suhu melebihi $21^{\circ} \mathrm{C}$, sapi perah asal daerah sedang akan mengalami kesulitan adaptasi dan akan menunjukkan gejala penurunan produksi susu. Jika sapi tersebut diternakkan di daerah tropis dengan suhu lingkungan rata-rata di atas $23^{\circ} \mathrm{C}$, maka produksi susu yang dicapai tidak sebanyak produksi susu di daerah asalnya.

$\mathrm{CR}$ (Conception Rate)

Angka konsepsi digunakan untuk mengetahui tingkat fertilitas ternak disuatu wilayah. Semakin besar presentase angka konsepsi maka tingkat fertilitasnya semakin besar. Begitu pula sebaliknya, apabila presentase konsepsi angka konsepsi rendah maka tingkat fertilitasnya juga rendah. Data tentang hasil penelitian berdasarkan pengamatan CR dapat dilihat pada Tabel 1,

Tabel 1. Hasil penelitian berdasarkan pengamatan CR di peternakan Bapak Syaiful bahri

$\begin{gathered}\text { Jumlah sapi yang di inseminasi (30 } \\ \text { ekor) }\end{gathered}$
$\begin{gathered}\text { Conception Rate } \\ \text { (CR) }\end{gathered}$




\begin{tabular}{|c|c|c|c|}
\hline $1 \mathrm{x}$ & $2 \mathrm{x}$ & $3 \mathrm{x}$ & \\
\hline 19 & 11 & 4 & $63,3 \%$ \\
\hline
\end{tabular}

Sumber: Data Primer Terolah 2012

Dari tabel di atas dapat diketahui bahwa nilai CR di peternakan milik Bapak Syaiful Bahri sebesar 63,3\%, yang artinya dari 30 ekor sapi yang pertama kali dilakukan IB 63,3\% bunting atau 19 ekor sapi. Dari nilai tersebut dapat disimpulkan bahwa angka konsepsi di peternakan Bapak Nur Trianto di standar. Dimana menurut anonymous (2011) bahwa angka konsepsi yang normal bersekitar antara $60 \%$ sampai $80 \%$.

Angka kebuntingan diperoleh dari pemeriksaan kebuntingan dengan cara palpasi per rectal pada pada umur kebuntingan 60-63 hari. Pada palpasi per rectal diperoleh kondisi cornua utery yang tidak sama besar (asimetris) dan ukuran fetus sebesar tikus. Hal ini sesuai dengan pendapat Edna (2011) palpasi per rectal terhadap uterus, ovaria dan pembuluh darah uterus adalah cara diagnosa-diagnosa kebuntingan yang paling praktis dan akurat pada sapi. Edna (2011) mengatakan palpasi per rectal merupakan cara yang lebih mudah, praktis, murah, dan cepat. Ini dapat dilakukan setelah 50-60 hari perkawinan.

Angka konsepsi ditentukan oleh 3 faktor yaitu:

\section{a. Fertilitas pejantan}

Semen beku yang digunakan inseminator di peternakan Bapak Syaiful Bahri adalah dari BBIB Singosari, dimana di BBIB tersebut dihasilkan semen yang berkualitas yang di ambil dari sapi pejantan-pejantan berkualitas, dan selanjutnya dipelihara secara standar agar terjaga fertilitasnya tujuannya untuk menghasilkan straw yang benar-benar berkualitas.

Dengan menggunakan straw yang di ambil dari semen sapi yang terjaga fertilitasnya, sangat membantu di dalam keberhasilan IB di peternakan ini yang menghasilkan angka konsepsi yang tinggi yaitu sebesar 63,3\%.

b. Fertilitas betina

Untuk menjaga fertilitas betina, peternak sudah melakukan manajemen pemeliharaan, pakan dan kesehatan dengan baik walaupun belum bisa dikatakan optimal. Untuk makanan ternaknya selain diberi makan hijauan, juga diberi konsentrat untuk mempertahankan berat badan yang ideal, karena dengan mempertahankan berat badan yang ideal maka fertilitas tidak akan terlambat dan siap untuk nenjadi indukan yang siap dibuahi untuk menghasilkan keturunan. Selain itu peternak juga menjaga kesehatan ternaknya antara lain dengan memendikannya, menjaga kebersihan kandang, dan memberi vitamin. Pemberian air minum juga secara adlibitum sehingga tidak kekurangan air minum. Dengan menjaga fertilitas betinanya, maka peternak menjadi untung karena presentase kegagalan IB bisa diminimalisir.

c. Teknik perkawinan

Inseminasi Rectovalgina adalah teknik yang digunakan oleh petugas inseminasi di peternakan ini, karena teknik ini biasanya banyak digunakan oleh inseminator, yaitu teknik inseminasi yang digunakan dengan jalan memasukkan satu tangan yang bersarung tangan yang dilumuri zat pelican kedalam rectum sapi, kemudian alat inseminasi dimasukkan ke dalam vagina dengan bantuan tangan yang di arahkan ke servik dan dimasukkan kepossisi 4 . Hal ini sesuai dengan pendapat Ihsan (1992) bahwa posisi semen yang tepat yaitu pada posisi 4 atau pada bagian pertemuan antara badan uterus dan os servik karena pada posisi ini spermatozoa dapat menyebar keseluruh uterus. Sedangkan deposisi semen pda posisi 2 dan 3 dirasa kurang efektif karena lipatan-lipatan anular serviks merupakan salah satu penghalang bagi jalannya spermatozoa. 
Melalui teknik inseminasi rectovaginal diharapkan keberhasila IB menjadi tinggi karena teknik perkawinan merupakan salah satu factor keberhasilan IB.

Faktor-faktor di atas sesuai dengan pendapat Edna (2011) bahwa, angka konsepsi ditentukan tiga faktor yaitu, fertilitas pejantan, fertilitas betina dan inseminator.

\section{S/C (Service per Conception)}

Data hasil penelitian berdasarkan pengamatan S/C dapat dilihat pada Tabel 2, dan untuk perhitungannya lengkapnya dapat dilihat pada lampiran 2 .

Tabel 2. Hasil penelitian berdasarkan pengamatan S/C di peternakan Bapak Nur Trianto

\begin{tabular}{|c|c|c|c|}
\hline \multicolumn{3}{|c|}{$\begin{array}{c}\text { Jumlah sapi yang di inseminasi (30 } \\
\text { ekor) }\end{array}$} & $\begin{array}{c}\text { Service per Conception } \\
\text { (S/C) }\end{array}$ \\
\hline $1 \mathrm{x}$ & $2 \mathrm{x}$ & $3 \mathrm{x}$ & \\
\hline 19 & 11 & 4 & 1,5 \\
\hline
\end{tabular}

Sumber: Data Primer Terolah 2012

Dari data di atas dapat diketahui bahwa nilai S/C di peternakan Bapak Syaiful Bahri adalah 1,5, yang artinya dari 30 ekor sapi untuk terjadinya suatu kebuntingan memerlukan 1,5 perkawinan. Dari data tersebut dapat diketahui bahwa S/C dilokasi penelitian sangat baik. Hal ini sesuai pendapat Feradis (2010) yang menyatakan bahwa S/C yang normal berkisar antara 1,6 sampai 2,0. Makin rendah nilai tersebut, makin tinggi kesuburan hewan-hewan betina dalam kelompok tersebut. Sebaliknya, makin tinggi nilai S/C maka makin rendahlah nilai kesuburan kelompok betina tersebut. Jadi sangat baiknya nilai S/C di peternakan Bapak Nur Trianto dapat dijadikan isyarat bahwa manajemen IB yang dilakukan oleh peternak maupun inseminator sudah sangat baik walaupun belum bisa dikatakan mempunyai keberhasilan tinggi.

Faktor-faktor yang mempengaruhi S/C dipeternakan ini adalah manajemen pemeliharaan dan manajemen IB. Anonymous (2011) mengatakan bahwa nilai S/C bergantung pada tingkat fertilitas semen dan kesuburan betina. Semen dengan tingkat fertilitas $70 \%$ dapat menghasilakn nilai $\mathrm{S} / \mathrm{C}=1,4$ dan pada tingkat fertilitas $90 \%$ menghasilkan nilai $\mathrm{S} / \mathrm{C}=1,1$.

\section{NRR (Non Return Rate)}

Data tentang hasil penelitian berdasarkan pengamatan NRR dapat dilihat pada Tabel 3, dan untuk perhitungan lengkapnya dapat dilihat pada lampiran 2.

Tabel 3. Hasil penelitian berdasarkan pengamatan NRR di peternakan Bapak Nur Trianto

\begin{tabular}{|c|c|c|}
\hline $\begin{array}{c}\text { Jumlah sapi yang di IB } \\
\text { (ekor) }\end{array}$ & $\begin{array}{c}\text { Jumlah sapi yang } \\
\text { tidak minta kawin } \\
\text { kembali (ekor) }\end{array}$ & $\begin{array}{c}\text { Non Return Rate } \\
\text { (NRR) }\end{array}$ \\
\hline 30 & 19 & $63,3 \%$ \\
\hline
\end{tabular}

Sumber: Data Primer Terolah 2012

Dari tabel di atas dapat diketahui nilai hasil perhitungan dari NRR sapi perah di peternakan Bapak Nur Trianto memperoleh hasil sebesar 63,3\% atau 19 ekor sapi, yang artinya dari 30 ekor sapi yang di IB, sebanyak 19 ekor sapi yang tidak minta kawin kembali dan dengan total pengulangan IB sebanyak 15 kali. Hal ini membuktikan bahwa presentase ternak yang tidak minta kawin kembali setelah di lakukan IB adalah baik, yaitu dengan melihat lebih dari setengah populasi sapi yang tidak estrus kembali. 
Beberapa faktor yang mempengaruhi tingginya presentase NRR di peternakan ini adalah ketepatan peternak mendeteksi birahi, kondisi ternak betina yang sehat, dan keterampilan petugas inseminator dalam melakukan inseminasi.

a. Ketepatan peternak mendeteksi birahi

Dari hasil penelitian menunjukkan bahwa dalam mendeteksi birahi, peternak sudah dapat mengetahui tanda-tandanya. Pengetahuan tanda-tanda birahi diperoleh antara lain dari inseminator serta pengalaman selama memelihara ternak. Dari pengetahuan serta pengalaman tersebut peternak mengamati tanda-tanda birahi dengan melihat perubahan tingkah laku ternaknya, antara lain melenguh, menggosok-gosokkan badannya ke ternak lain dan keluar lender dari vulvanya. Hal ini sesuai dengan pendapat Suyadi (2002) yang mengatakan bahwa pada umumnya sapi yang mengalami birahi akan mengalami perubahan tingkah laku seperti gelisah, aktifitas bergerak meningkat, selalu berteriak-teriak, selalu mengeluarkan urin dan kotoran, nafsu makan menurun, sering mengusap kepalanya pada punggung atau pantat, ekor terangkat ke atas menyamping, menggosok-gosokkan badannya ke ternak lain atau kedinding, menaiki ternak lainnya atau diam bila dinaiki ternak lainnya.

b. Keterampilan petugas inseminator

Rata-rata petugas inseminator sudah berpengalaman dalam melaksanakan tugas mengiseminasi ternak sapi. Bagitu pula dengan para petugas inseminator yang ada di peternakan Bapak Nur Trianto, petugas inseminator telah melaksanakan IB sesuai dengan prosedur mulai dari deteksi birahi untuk menentukan waktu optimum perkawinan, penanganan semen beku, teknik pelaksanaan IB.

Walaupun inseminator sudah terampil, tetapi terkadang masih mengalami kesulitan terutama bila mengisenminasi ternak muda atau dara, ini terjadi karena sapi muda atau dara baru pertama kali melakukan perkawinan, biasanya sapi yang baru malakukan perkawinan kondisi serviknya belum terbuka sehingga memerlukan keterampilan tersendiri, hal ini berbeda dengan sapi induk yang sudah pernah atau sering melakukan perkawinan.

c. Kondisi ternak betina yang sehat

Keberhasilan IB salah satunya ditentukan oleh kondisi ternak betina yang sehat. Dari hasil pengamatan rata-rata keadaan umum calon induk ternak sapi betina di peternakan ini dapat dikatan sehat, hal ini dapat dilihat dari keadaan ternak betina yang siap menjalani proses perkawinan baik siap secara fisik maupun dewasa kelamin. Selain itu peternak sangat memperhatikan kesehatan ternaknya dengan memandikan, memberi vitamin, selin itu kandang juga dibersihkan dan juga diberi pakan yang memadai. Kondisi ternak betina yang sehat merupakan salah satu faktor yang mempengaruhi rendahnya nilai NRR dipeternakan ini yaitu sebesar $63,3 \%$. Karena dengan ternak betina yang sehat maka keberhasilan IB juga tinggi dan hal ini tentu saja menguntungkan peternak.

Faktor-faktor di atas sesuai dengan pernyataan Anonymous (2011) yang mengatakan faktor-faktor yang mempengaruhi nilai NRR antara lain metode pengukuran, waktu IB sampai pemeriksaan estrus berikutnya, tingkat kesuburan, penyakit, diagnose kebuntingan, pelaporan dan sebagainya.

NRR merupakan kriteria umum yang digunakan secara luas untuk menentukan kebuntingan. Meskipun demikian terdapat beberapa kelemahan yaitu tidak semua ternak dapat di amati secara cermat sehingga tidak semua ternak yang kembali birahi diketahui.

\section{Kesimpulan Dan Saran}

Kesimpulan 
Berdasarkan hasil penelitian pada sapi perah di peternakan Bapak Syaiful Bahri dapat di ambil kesimpulan bahwa efisiensi reproduksi sapi perahnya baik yang dicirikan dengan nilai CR di peternakan Bapak Syaiful Bahri adalah sebesar 63,3\%. Hal ini berarti dari 30 ekor sapi yang di IB pertama sebanyak 63,3\% mengalami bunting atau 19 ekor sapi. Hal ini menunjukkan bahwa konsepsinya di atas standar. Nilai S/C di peternakan Bapak Syaiful Bahri adalah sebesar 1,5. Yang artinya untuk terjadinya suatu kebuntingan memerlukan rata-rata 1,5 kali perkawinan. Hal ini menunjukkan bahwa tingkat kesuburan hawan-hewan betina di peternakan Bapak Syaiful Bahri sangat baik dan mempunyai manajemen pemeliharaan yang baik. Nilai NRR di peternakan Bapak Syaiful Bahri adalah sebesar 63,3\%, hal ini berarti bahwa sapi perah yang tidak minta kawin kembali setelah dilakukan IB adalah 63,3\% atau sebanyak 19 ekor sapi.

Saran

Saran yang diberikan dari hasil penelitian adalah peternak hendaknya selalu melengkapi catatan reproduksi maupun kesehatan ternaknya agar mempermudah dalam penanganan ternak jika terjadi permasalahan, hal ini juga sangat diperlukan untuk meningkatkan efisiensi reproduksi. Untuk mendapatkan efisiensi reproduksi yang lebih baik lagi, maka dibutuhkan kerja sama dari Dinas Peternakan dan Instansi terkait dalam memberikan penyuluhan mengenai tata cara beternak sapi perah yang lebih baik lagi kepada peternak, selain itu juga untuk meningkatkan pengetahuan peternak dalam bidang reproduksi seperti pengetahuan tentang birahi dan lain sebagainya.

\section{Daftar Pustaka}

Al Anshori, F. 2011. Efisiensi Reproduksi.http://biologinews.blogspot.com/2011/02/efisiensireproduksi.html. Diakses pada tanggal 7 Juni 2012.

Anonymous. 2007. Measures of Reproductive Performance. http://www.fao.org. Diakses pada tanggal 7 Juni 2012.

2011. Inseminasi Buatan. https://sites.google.com/site/bimtekib/. Diakses pada tanggal 7 Juni 2012.

2011. Pegangan Inseminator Swasta.

http://www.google.co.id/url?sa=t\&rct=j\&q=pegangan+peserta+inseminator\&source=web\&c $\mathrm{d}=1 \&$ ved=0CE4QFjAA\&url=http\%3A\%2F\%2Fdisnaksulsel.info\%2Findex.php\%3Fo ption\%3Dcom_docman\%26task\%3Ddoc downlo. Diakses pada tanggal 7 Juni 2012.

2011. Manajemen Reproduksi Pada Sapi Perah (Penanganan Reproduksi).http://rismanismail2.wordpress.com/2011/12/28/manajemen-reproduksipada-sapi-perah-penanganan-reproduksi/. Diakses tanggal 6 Juli 2012.

Blakely, J and D.H. Bade. 1991. Ilmu Peternakan, edisi ke- 4. Gadjah Mada University Press. Jogjakarta.

Basyir, A. 2009. Meningkatkan Efisiensi Reproduksi Melalui Kelahiran Pedet Kembar.http://www.vet-indo.com/Artikel-Member/Meningkatkan-EfisiensiReproduksi-melalui-Kelahiran-Pedet-Kembar.html. Diakses pada tanggal 7 Juni 2012. 
Disnak, E. 2011. Fisiologi Dan Pemeriksaan Kebuntingan Pada Sapi.

http://ednadisnak.blogspot.com/2011/10/fisiologi-dan-pemeriksaan-kebuntingan.html.

Diakses pada tanggal 7 Juni 2012.

. 2011. Reproduksi Ternak Ruminansia.

http://ednadisnak.blogspot.com/2011/01/reproduksi-ternak-ruminansia.html?m=1. Diakses tanggal 6 Juli 2012.

Feradis. 2010. Bioteknologi Reproduksi Pada Ternak. Alfabeta. Bandung.

Hafez, E.S.E. 1993. Reproduction in Farm Animals. 6th Ed. Philadelphia: Lea \& Febiger. part 4: reproductive failure.

Ihsan, M.N. 1992. Inseminasi Buatan. LUV-Universitas Brawijaya. Malang.

Maura, E. 2011. Bangsa-Bangsa Sapi Perah.

http://ketekdekil.blogspot.com/2011/02/bangsa-bangsa-sapi-perah.html. Diakses pada tanggal 7 Juni 2012.

Niazi, A. A. K. 2003. Comparative Studies on the Reproductive Efficiency of Imported and Local Born Friesian Cows in Pakistan. Journal of Biological Sciences, 3.

Prihadi, S. 1997. Dasar Ilmu Ternak Perah. Fakultas Peternakan UGM. Jogjakarta.

Ramadhan, N. 2011. Penelitian Sapi Perah.

http://ag1992.blogspot.com/2011/11/penelitian-sapi-perah.html?m=1.Diakses tanggal $6 \mathrm{Juli}$ 2012.

Tissa. 2010. Efisiensi Reproduksi Sapi Perah.

http://tissacuitzz.blogspot.com/2010/12/efisiensi-reproduksi-sapi-perah.html. Diakses pada tanggal 7 Juni 2012.

Suyasa. 1999. Pemanfaatan Probiotik Dalam Pengembangan Sapi Potong. Jurnal Pengkajian dan Pengembangan Teknologi Pertanian. Vol 2 No 1. Pusat Penelitian Sosial Ekonomi Pertanian. Bogor.

Wijaya, I. 2008. Ilmu Reproduksi Ternak Mata Kuliah Peternakan. Jurusan Produksi Ternak Fakultas Peternakan Universitas Udayana.2008. http://one.indoskripsi.com. Diakses pada tanggal 7 Juni 2012. 